\title{
Distinct profiles of antibodies to Kaposi sarcoma- associated herpesvirus antigens in patients with Kaposi sarcoma, multicentric Castleman's disease, and primary effusion lymphoma
}

\author{
Peter D Burbelo ${ }^{1 *}$, Alexandra T Issa ${ }^{1}$, Kathryn H Ching ${ }^{1}$, Kathleen M Wyvill ${ }^{3}$, Richard F Little ${ }^{3}$, Michael J ladarola',
} Joseph A Kovacs' ${ }^{2}$, Robert Yarchoan ${ }^{3}$

From $12^{\text {th }}$ International Conference on Malignancies in AIDS and Other Acquired Immunodeficiencies (ICMAOI)

Bethesda, MD, USA. 26-27 April, 2010

\section{Clinical background}

Kaposi sarcoma-associated herpesvirus (KSHV), also called human herpesvirus- 8 (HHV-8), is the causative agent of all forms of Kaposi sarcoma (KS), as well as two rare B-cell HIV lymphoproliferative disorders, primary effusion lymphoma (PEL) and multicentric Castleman's disease (MCD). Like other herpesviruses, KSHV has two phases of gene expression, latent and lytic. In $\mathrm{KS}$, many of the KSHV-infected spindle cells express only latent genes, while a small percentage express lytic genes. By contrast, a substantial percentage of MCD cells express lytic KSHV genes. The majority of PEL cells express KSHV latent genes, but in addition can show limited expression of certain lytic genes. Given the differential expression of KSHV lytic and latent proteins in KS, PEL, and MCD, we hypothesized that different antibody profiles to KSHV antigens might distinguish these diseases.

\section{Materials and methods}

Antibodies were evaluated in sera from patients or volunteers under IRB-approved protocols at the $\mathrm{NIH}$ Clinical Center, NIAID, and the NCI including from 35 patients with KS, 14 with both MCD and KS (MCD +/KS+), 6 with MCD but no KS (MCD+/KS), 5 with $\mathrm{PEL}$, and $34 \mathrm{KSHV}$-uninfected controls. Luciferase

\footnotetext{
*Correspondence: burbelop@nidcr.nih.gov

'Neurobiology and Pain Therapeutics Section, Laboratory of Sensory Biology, NIDCR, NIH, Bethesda, MD, USA

Full list of author information is available at the end of the article
}

Immunoprecipitation Systems (LIPS) was used for profiling antibodies to latent and lytic KSHV antigens.

\section{Results}

Using LIPS, antibodies against the lytic antigen K8.1 were 5-fold higher in MCD than in KS patients. In contrast, markedly higher antibodies to $\mathrm{v}$-cyclin, a latent KSHV gene, were found in the KS and PEL patients compared to the MCD. Antibodies to another latent antigen, LANA, were also markedly higher in the KS compared to the MCD patients. Antibodies to the sum of latent antigens $\mathrm{v}$-cyclin and LANA were 27 -fold higher in KS compared to MCD patients $(\mathrm{p}<0.0001)$. The sum of anti-v-cyclin and anti-LANA antibody titers discriminated patients with KS without MCD from those with MCD and KS with 93\% sensitivity and $83 \%$ specificity.

\section{Conclusion}

These results suggest that antibody responses to lytic and latent KSHV antigens differ between KS, MCD, and PEL.

\footnotetext{
Acknowledgements

The authors thank the patients who volunteered for these studies. This work was supported by the Intramural Research Program of the NIH, National Institute of Dental and Craniofacial Research, NIH Clinical Center, and National Cancer Institute and, in part, by a Bench to Bedside award from the $\mathrm{NIH}$ Clinical Center.

This article has been published as part of Infectious Agents and Cancer Volume 5 Supplement 1, 2010: Proceedings of the $12^{\text {th }}$ International Conference on Malignancies in AIDS and Other Acquired
} 
Immunodeficiencies (ICMAOI). The full contents of the supplement are available online at http://www.biomedcentral.com/1750-9378/5?issue=S1

\section{Author details}

'Neurobiology and Pain Therapeutics Section, Laboratory of Sensory Biology, NIDCR, NIH, Bethesda, MD, USA. ${ }^{2}$ Critical Care Medicine Department, Clinical Center, NIH, Bethesda, MD, USA. ${ }^{3} \mathrm{HIV}$ and AIDS Malignancy Branch, Center for Cancer Research, NCl, NIH, Bethesda, MD, USA.

Published: 11 October 2010

doi:10.1186/1750-9378-5-S1-A20

Cite this article as: Burbelo et al:. Distinct profiles of antibodies to

Kaposi sarcoma-associated herpesvirus antigens in patients with Kaposi

sarcoma, multicentric Castleman's disease, and primary effusion

lymphoma. Infectious Agents and Cancer 2010 5(Suppl 1):A20.

\section{Submit your next manuscript to BioMed Central} and take full advantage of:

- Convenient online submission

- Thorough peer review

- No space constraints or color figure charges

- Immediate publication on acceptance

- Inclusion in PubMed, CAS, Scopus and Google Scholar

- Research which is freely available for redistribution

Submit your manuscript at www.biomedcentral.com/submit 